\title{
甘蕉の染色體 數“
}

\author{
山下孝介
}

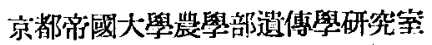

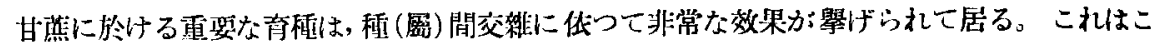

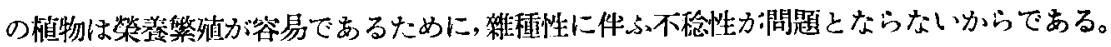

從來の甘蕉の育棰は染色蹬の行動或は數と殆ど無關係に行はれて來たすのであるが, 今後は

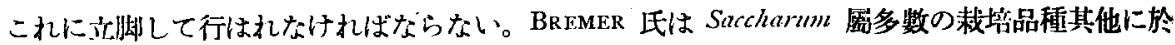

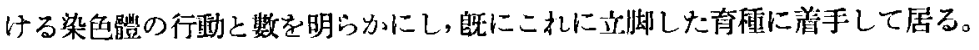
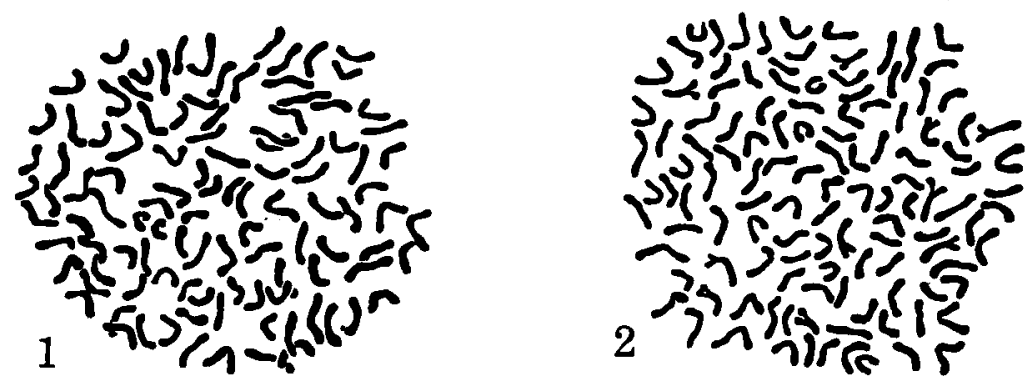

甘蕉の㖣細胞染色體 $\times$ ca 2500

Abb 1. 2725 POJ $(2 n=107)$ Abb 2. 2878 POJ $(2 n=119)$

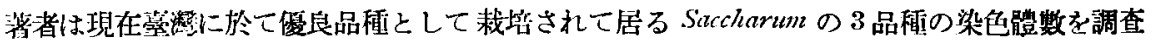

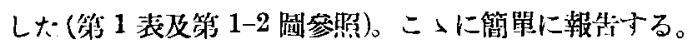

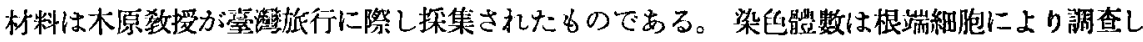

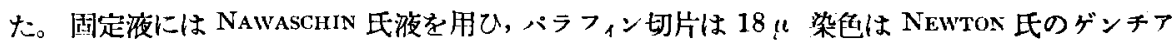
ン・バイオレット法に低つた。

第 1 表 供試材料之染色體數

\begin{tabular}{|c|c|c|c|}
\hline 供 鶁 材 料 & 染色喑數 $(2, z)$ & & 圖 \\
\hline $2725 \mathrm{POJ}$ & 107 & 第 & 1 成 \\
\hline $2878 \mathrm{POJ}$ & 119 & 第 & 2 墖 \\
\hline $2883 \mathrm{POJ}$ & $115 \pm$ & & - \\
\hline
\end{tabular}

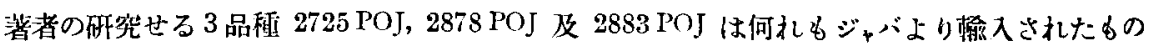
で, 既に年月を經て居るが, 本砳究に低つて染色骼數は BRFMER 氏 $(1928,1931,1934)$ が彼地に 於て调焦せるものと昸々同樣であることかわかかな

* Vamashita, K. Chromosomenzahlen einiger Zuckerrohr-Sorten in Formosa. 
材料を與へられ御指䢙を睗つた木原教授に厚く感謝の意を表する。

\title{
引用 文 献
}

BRFMER, G. 1928. De cytologie van het suikerriet. IV. Een cytologisch onderzoek der bastarden tusschen Saccharum officinarum en Saccharım spontaneum. Mededeelingen van het Proefstation 1928, No. I I : 565-696.

, I931. Idem V. Een onderzoek over de somatische chromosomenaantallen van suikerriet. Ibid. 1931, No. 13: 583-607.

- I934. Idem. VII. Een cytologisch onderzoek van een vijftigtal in 1929-1930 op Java geïmporteerde rietsoorten. Ibid. 1934, No. $5: 14 \mathrm{I}-166$.

\section{Chromosomenzahlen einiger Zuckerrohr-Sorten in Formosa}

\author{
Kosuke Yamashita
}

Laboratory of Genetics, Biological Institute, Kyoto Imperial University

\section{Zusammenfassung}

Die Chromosomenzahlen von 3 Zuckerrohr-Sorten in Formosa wurden festgestellt. Die Resultate sind in folgender Tabelle angegeben.

Tab. 1. Material und Chromosomenzahlen

\begin{tabular}{c|c|c}
\hline \hline Material & Chromosomenzahlen $(2 n)$ & Abb. \\
\hline 2725 POJ & 107 & 1 \\
2878 POJ & 119 & 2 \\
2883 POJ & $115 \pm$ & - \\
\hline
\end{tabular}

